\title{
CNS Leptin Action Modulates Immune Response and Survival in Sepsis
}

\author{
Johannes Tschöp, ${ }^{1,2}$ Ruben Nogueiras, ${ }^{3}$ Sarah Haas-Lockie, ${ }^{3,4}$ Kevin R. Kasten, ${ }^{2}$ Tamara R. Castañeda, ${ }^{3}$ Nadine Huber, ${ }^{2}$ \\ Kelsey Guanciale, ${ }^{2}$ Diego Perez-Tilve, ${ }^{3}$ Kirk Habegger, ${ }^{3}$ Nickki Ottaway, ${ }^{3}$ Stephen C. Woods, ${ }^{3}$ Brian Oldfield, ${ }^{4}$ \\ Iain Clarke, ${ }^{4}$ Streamson Chua Jr, ${ }^{5}$ I. Sadaf Farooqi, ${ }^{6}$ Stephen 0’Rahilly, ${ }^{6}$ Charles C. Caldwell, ${ }^{2}$ and Matthias H. Tschöp ${ }^{3,7}$ \\ ${ }^{1}$ Clinic for Anaesthesiology, Klinikum Großhadern, Ludwig Maximilians University, D-81375 Munich, Germany, ${ }^{2}$ Department of Surgery, ${ }^{3}$ Metabolic \\ Disease Institute, Division of Endocrinology, Department of Internal Medicine, University of Cincinnati College of Medicine, Cincinnati, Ohio 45267, \\ ${ }^{4}$ Department of Physiology, Monash University, Melbourne, Victoria 3800, Australia, ${ }^{5}$ Departments of Medicine and Neuroscience, Albert Einstein College \\ of Medicine, Bronx, New York 10461, 'University of Cambridge Metabolic Research Laboratories, Institute of Metabolic Science, Addenbrooke's Hospital, \\ Cambridge CB2 0QQ, United Kingdom, and 7Department of Pharmacology, German Institute of Human Nutrition, D-14558 Potsdam-Nuthetal, Germany
}

Sepsis describes a complex clinical syndrome that results from an infection, setting off a cascade of systemic inflammatory responses that can lead to multiple organ failure and death. Leptin is a $16 \mathrm{kDa}$ adipokine that, among its multiple known effects, is involved in regulating immune function. Here we demonstrate that leptin deficiency in $o b / o b$ mice leads to higher mortality and more severe organ damage in a standard model of sepsis in mice [cecal ligation and puncture (CLP)]. Moreover, systemic leptin replacement improved the immune response to CLP. Based on the molecular mechanisms of leptin regulation of energy metabolism and reproductive function, we hypothesized that leptin acts in the CNS to efficiently coordinate peripheral immune defense in sepsis. We now report that leptin signaling in the brain increases survival during sepsis in leptin-deficient as well as in wild-type mice and that endogenous CNS leptin action is required for an adequate systemic immune response. These findings reveal the existence of a relevant neuroendocrine control of systemic immune defense and suggest a possible therapeutic potential for leptin analogs in infectious disease.

\section{Introduction}

Scattered evidence from clinical experience suggests that the CNS may play a functionally relevant role in maintaining an efficiently coordinated immune system. For example, brain-injured patients admitted to intensive care units have an elevated risk to acquire infections (Dziedzic et al., 2004), and infections are a leading cause of mortality in patients with acute CNS trauma (Meisel et al., 2005). Increased susceptibility to infectious agents is believed to be partly attributable to transient immunodepression triggered by brain damage (Prass et al., 2003). This concept is further supported by observations suggesting that strokeinduced immunodepression increases the susceptibility to infection, and infection in turn is the most relevant complication in stroke patients (Dirnagl et al., 2007). A series of elegant studies by Tracey and colleagues indicates that the autonomic nervous system (ANS), especially the vagus nerve and the cholinergic anti-

Received Sept. 29, 2009; revised Feb. 25, 2010; accepted March 12, 2010.

This work was supported by National Institutes of Health Grant R01 GM72760 and National Institute of Diabetes and Digestive and Kidney Diseases Grants 59630, 69987, and 56863 (S.C.W., M.H.T.), and National Institute of Diabetes and Digestive and Kidney Diseases Obesity Center Grant P01DK26687 (S.C.). We thank Kim Brown, Paul T. Pfluger, and Randy Seeley for research assistance, helpful discussions, and manuscript editing.

M.H.T. is a Scientific Advisory Board Member for Marcadia Biotech and Acylin Inc. and a Consultant for Ambrx Inc. Correspondence should be addressed to either of the following: Dr. Matthias H. Tschöp, Metabolic Diseases Institute, Division of Endocrinology, Department of Internal Medicine, University of Cincinnati College of Medicine, 2180 E. Galbraith Road, Cincinnati, OH 45237, E-mail: matthias.tschoep@uc.edu; or Dr. Charles C. Caldwell, Department of Surgery, University of Cincinnati College of Medicine, 231 Albert Sabin Way, MSB SRU G479 ML 0558, Cincinnati, 0H 45267-0558, E-mail: charles.caldwell@uc.edu.

DOI:10.1523/JNEUROSCI.4875-09.2010

Copyright $\odot 2010$ the authors $\quad 0270-6474 / 10 / 306036-12 \$ 15.00 / 0$ inflammatory pathway, robustly regulates cytokine-mediated damage in local and systemic infectious disease (Czura and Tracey, 2005; Huston et al., 2007; Tracey, 2007). Interestingly, Tracey and colleagues also report that the systemic inflammatory response during endotoxemia is controlled by central muscarinic cholinergic pathways (Pavlov and Tracey, 2006; Pavlov et al., 2006). However, the molecular underpinnings of an obviously fine-balanced interplay between the CNS and the immune system remain essentially unknown.

Leptin is a $16 \mathrm{kDa}$ adipocytes-derived circulating cytokine (Zhang et al., 1994) known to achieve the vast majority of its biological effects by acting in the CNS (Zhang et al., 1994; Campfield et al., 1995; Halaas et al., 1995; Pelleymounter et al., 1995; Friedman, 2002). Some of the well studied biological roles of leptin are its CNS-mediated participation in the control of food intake, body weight (Campfield et al., 1995; Halaas et al., 1995; Pelleymounter et al., 1995), and reproductive function (Barash et al., 1996; Chehab et al., 1996, 1997; Blüher and Mantzoros, 2007). However, a considerable body of data also suggests that leptin may be involved in the regulation of immune responses in both rodents and humans (Flier, 1998; Lord et al., 1998; Fantuzzi and Faggioni, 2000; Farooqi et al., 2002; De Rosa et al., 2006; Tilg and Moschen, 2006; Lago et al., 2008). Leptin can functionally activate human monocytes in vitro by inducing the production of cytokines such as tumor necrosis factor- $\alpha$ and interleukin-6 (IL-6) (Santos-Alvarez et al., 1999). Lord et al. (1998) first reported that leptin has a specific effect on T-lymphocyte responses by differentially regulating the proliferation of naive and memory $\mathrm{T}$ cells. Leptin increased Th1 and 
suppressed Th2 cytokine production (Lord et al., 1998). The possibility that these potent effects of leptin on the immune system is a result of actions in the CNS rather than directly on immune cells has been suggested previously (Flier, 1998; Lord et al., 1998) but not yet rigorously tested.

Human congenital leptin deficiency is rare, with $<20$ patients reported worldwide to date (Ozata et al., 1999; Farooqi et al., 2002). The phenotype is characterized by severe early-onset obesity, hypogonadatropic hypogonadism, and an increased frequency of infections. T-cell number and function is impaired in patients with congenital leptin deficiency with a decrease in CD4+ T cells, reduced T-cell proliferation to a number of antigens, and a predominant Th2 cytokine response (Farooqi et al., 2002). These findings are consistent with the T-cell responses seen in leptin-deficient $o b / o b$ mice and are normalized when therapeutic doses of recombinant human leptin are administered to these patients (Farooqi et al., 2002).

Sepsis, which is defined as a systemic inflammatory response syndrome (SIRS) that occurs during infection (Santos-Alvarez et al., 1999), is associated with several clinical conditions and high mortality rates (Takahashi et al., 2004). This definition of SIRS, however, does not encompass fully the immunologic derangements that accompany the septic process. As sepsis progresses, immunodepression can become severe, leaving an already vulnerable patient ill-equipped to fight off the primary or new secondary infections (Hotchkiss and Karl, 2003). With no convincingly effective specific therapies available so far, the predominantly supportive treatment does not reduce the death rate of sepsis significantly (Zanotti and Kumar, 2002).

Here we demonstrate, using a well established murine model of sepsis, that leptin action in the CNS optimizes the immune response and increases survival in normal as well as in leptindeficient mice. We also demonstrate that leptin-deficient $o b / o b$ mice are highly susceptible to sepsis and have more severe organ damage than controls. These studies, using pharmacological as well as genetic approaches, suggest that leptin-initiated neuroendocrine pathways play an important role in the functional coordination of the systemic immune response.

\section{Materials and Methods}

Mice. Male C57BL/6J wild-type (WT) (6-10 weeks old) and leptindeficient C57BL/6J-ob/ob (ob/ob), as well as leptin receptor-deficient mice C57BL/6J- $d b / d b(d b / d b)$ were purchased from The Jackson Laboratory and maintained under pathogen-free conditions. The mice had 12 backcrosses on the C57BL/6J strain. All mice were kept in standard environmental conditions (lights on from 7:00 A.M. to 7:00 P.M.) and were fed with a commercial pelleted diet and water ad libitum.

Male C57BL/6J wild-type mice between 8 and 10 weeks of age (The Jackson Laboratory) were fed with high-fat diet (58\% kcal fat with sucrose; Surwit Diet; purchased from Research Diets).

Neuron-specific enolase (NSE)-cre and Lepr ${ }^{\text {flox/flox }}$ mice were generated as reported previously (Kowalski et al., 2001; Chua et al., 2004; de Luca et al., 2005) and were fed with a commercial pelleted diet and water ad libitum.

All experiments involving animals were performed under protocols approved by the Institutional Animal Care and Use Committee of the University of Cincinnati.

Cecal ligation and puncture. Male mice between 8 and 10 weeks of age (21-29 $\mathrm{g}$ for WT; 49-57 $\mathrm{g}$ for $o b / o b$ ) were used. Polymicrobial sepsis was induced similarly as described (Murphey et al., 2004). Briefly, the cecal ligation and puncture (CLP) operations were always performed between 8:00 A.M. and 1:00 P.M. Mice were anesthetized by 2.5\% isoflurane in oxygen via facemask. The skin was shaved and disinfected. After a $1 \mathrm{~cm}$ laparatomy (midline incision through the linea alba while avoiding injury to the abdominal vasculature), the latter $80 \%$ of the cecum was ligated with a 3-0 silk tie (Ethicon) and punctured once on the antimesenterial side with a 23 gauge needle. A small amount of the bowel contents was extruded through the puncture hole to ensure a full thickness perforation. Care was taken not to obstruct the bowel, and this was tested after the animals' death. The cecum was replaced in its original location, and the midline incision was closed by two-layer suture with 4-0 silk (Schein). The animals were resuscitated with $1 \mathrm{ml}$ of sterile saline subcutaneously and kept on a heating blanket with additional oxygen supply for $1 \mathrm{~h}$. Sham-treated controls underwent the same surgical procedures (i.e., laparotomy and resuscitation), but the cecum was neither ligated nor punctured.

Leptin administration (intraperitoneal). Recombinant murine leptin (Henry et al., 1999) was replaced intraperitoneally in $o b / o b$ and WT mice ( $1 \mu \mathrm{g} / \mathrm{g}$ body weight) at 9:00 A.M. and 6:00 P.M. before and after CLP for a total of four injections before blood, peritoneal lavage and organ harvest. This leptin replacement protocol has been shown to achieve circulating leptin levels (Lord et al., 1998) and was chosen to incorporate the range of serum levels measured in humans (Considine et al., 1996).

Intracerebroventricular and peripheral minipumps. For experiments involving chronic intracerebroventricular leptin administration, 8- to 10week-old male WT and ob/ob mice were anesthetized with $2.5 \%$ isoflurane in oxygen for intracerebroventricular minipump implantation. A cannula was positioned in the right lateral cerebral ventricle (coordinates: anteroposterior, $-0.07 \mathrm{~mm}$ to bregma; lateral, $-0.12 \mathrm{~mm}$ to bregma; dorsoventral, $-0.2 \mathrm{~mm}$ to the cranial calota), fixed to the skull with cyanocrylate, and connected via a polyethylene catheter to a subcutaneous osmotic minipump (Alzet Osmotic Pumps; Durect Corporation) delivering leptin or vehicle (isotonic saline) (Nogueiras et al., 2007). After surgery, the animals received a single dose of $0.28 \mathrm{mg} / \mathrm{kg}$ buprenorphine (Buprenex; Reckitt Benckiser Healthcare). Leptin was infused at a concentration of $1 \mu \mathrm{g} / \mathrm{d}$ for $14 \mathrm{~d}$. CLP was induced after a $3 \mathrm{~d}$ surgery recovery.

For experiments involving peripheral leptin administration $(1 \mu \mathrm{g} / \mathrm{d})$, 8 - to 10 -week-old male $o b / o b$ mice were randomized and anesthetized with $2.5 \%$ isoflurane in oxygen. Osmotic minipumps were implanted subcutaneously in the upper back, delivering leptin or vehicle at a rate of $0.2 \mu \mathrm{l} / \mathrm{h}$ for $14 \mathrm{~d}$. After surgery, the animals received a single dose of 0.28 $\mathrm{mg} / \mathrm{kg}$ buprenorphine.

For all experiments, the osmotic minipumps were filled the evening before surgery and primed in a water bath overnight at $37^{\circ} \mathrm{C}$.

Effects of chronic central leptin action on systemic corticosterone. For intracerebroventricular leptin administration, 8-month-old, male C57BL/6 or $o b / o b$ mice purchased from The Jackson Laboratory were housed in individual cages under conditions of controlled temperature $\left(23^{\circ} \mathrm{C}\right)$ and illumination $(12 \mathrm{~h} \mathrm{light} /$ dark cycle). They were allowed $a d$ libitum access to water and pelleted low-fat laboratory chow. Food intake and body weight were measured $1 \mathrm{~d}$ before surgery and daily during the experimental phase in all groups. Blood plasma was also collected in all groups at these time points. Mice were anesthetized via inhalation of isoflurane and maintained in the anesthetic plane with constant administration throughout the procedure. Brain infusion cannulae were stereotaxically placed with their tips in the lateral cerebral ventricle using the following coordinates: $0.7 \mathrm{~mm}$ posterior to bregma, $1.2 \mathrm{~mm}$ lateral to the midsagittal suture, and to a depth of $2.0 \mathrm{~mm}$, with bregma and lambda at the same vertical dimension. Cannulae were fixed to these coordinates using veterinary-grade glue. A catheter tube (Alzet Brain Infusion Kit 3; Alzet Osmotic Pumps; Durect Corporation) was connected from the brain infusion cannula to an osmotic minipump flow moderator (model 1003D; Alzet). A subcutaneous pocket on the dorsal surface was created using blunt dissection, and the osmotic minipump was inserted. The incision was closed with veterinary-grade glue, and mice were kept warm until fully recovered. Mice were then infused with either saline or leptin $(1.0 \mu \mathrm{g} / \mathrm{d})$ (Henry et al., 1999) for $7 \mathrm{~d}$. After surgery, all mice received a single subcutaneous dose of $0.28 \mathrm{mg} / \mathrm{kg}$ buprenorphin (Buprenex; Reckitt Benckiser Healthcare). At the termination of all of the experiments, the animals were killed by decapitation, trunk blood was collected, and several tissues were removed and stored at $-80^{\circ} \mathrm{C}$ for later analysis.

Corticosterone analysis. Corticosterone levels were measured in plasma from all groups. Daily measurements were obtained from tail bleed- 
ings collected in EDTA coated capillary tubes (Sarstedt). Final sample made from trunk blood was obtained at the time of death in the presence of EDTA. Samples were centrifuged at 4500 relative centrifugal force for $15 \mathrm{~min}$ at $4^{\circ} \mathrm{C}$, and plasma was transferred to a fresh tube. Samples were diluted 1:200 and analyzed via radiolabeled immunoassay (MP Biomedicals).

Flow cytometry for surface staining. Cells were resuspended in fluorescent-activated cell sorting (FACS) buffer (PBS with $1 \%$ bovine albumin and $0.1 \%$ azide). Nonspecific binding to cells was controlled by adding 5\% rat serum (Invitrogen) and $1 \mu \mathrm{g} /$ tube Fc Block (BD Pharmingen) to the FACS buffer. Cells were stained in a five-color configuration using Pacific Blue-, FITC-, phycoerythrin-, adenomatous polyposis coli (APC)-, or Alexa Fluor 700-labeled antibodies.

Myeloid cells were surface stained with the following antibodies: Alexa Fluor 700-labeled CD11b (clone M1/70.15; BD Pharmingen), Alexa Fluor 488-labeled anti-neutrophil (clone 7/4; Serotec), and APC-labeled Gr-1 (clone RB6-8C5; BD Pharmingen). For phosphorylated p38 (pp38) staining, surface-stained samples were washed twice with PBS and fixed in $2 \%$ paraformaldehyde for $5 \mathrm{~min}$ at $37^{\circ} \mathrm{C}$. Samples were then washed twice with FACS buffer. The cell pellet was cooled for $1 \mathrm{~min}$ on ice, and then $1 \mathrm{ml}$ of $95 \%$ methanol was added to each sample while vortexing. Samples were kept on ice for additional $30 \mathrm{~min}$ and incubated overnight at $-20^{\circ} \mathrm{C}$. Then samples were washed with FACS buffer and stained with p-p38 for $20 \mathrm{~min}$ at $4^{\circ} \mathrm{C}$. Samples were washed thoroughly again with FACS buffer and run on a BD Biosciences LSR.

Bacterial counts. Bacterial counts were performed on aseptically harvested blood by cardiac puncture and peritoneal fluid. Peritoneal fluid was harvested from mice by peritoneal lavage after aseptic preparation of the abdominal wall, followed by injection of $9 \mathrm{ml}$ of sterile saline into the peritoneal cavity and aspiration of peritoneal fluid. Samples were serially diluted in sterile saline and cultured on tryptic soy agar pour plates. Plates were incubated at $37^{\circ} \mathrm{C}$ for $24 \mathrm{~h}$, and colony counts were performed.

Phagocytosis. The peritoneal fluid was harvested $24 \mathrm{~h}$ after CLP and mixed with fluorescently labeled (Alexa Fluor 488) Escherichia coli and opsonizing reagent (Invitrogen). This suspension was incubated at $37^{\circ} \mathrm{C}$ for $1 \mathrm{~h}$. After the incubation period, the excess bacteria were removed by washing three times with FACS buffer. Furthermore, to quench the fluorescence of adherent bacteria, trypan blue was added after the first acquisition and $1 \mathrm{~min}$ before the second acquisition. Quenching with trypan blue reduced the FITC fluorescence of adherent bacteria by excitation energy transfer (Szollosi et al., 1984; Hed, 1986).

Core temperature. Core temperature was measured rectally $24 \mathrm{~h}$ before and after CLP using a Fisher thermometer (Thermo Fisher Scientific).

Clinical chemistry. Levels of aspartate transaminase, alanine transaminase (ALT), and blood urea nitrogen (BUN) were measured in serum using a human assay system.

Western blot analysis. All samples were well mixed with equal volume of Laemli's buffer ( $0.125 \mathrm{M}$ Tris-Cl, $40 \%$ SDS, and 20\% glycerol, with 5\% $\beta$-mercaptoethanol). Mixed samples were denatured at $60^{\circ} \mathrm{C}$ for $20 \mathrm{~min}$. Protein extracts and standard markers (Bio-Rad) were resolved on a NuPage 12\% SDS-PAGE gel (Invitrogen) with $200 \mathrm{~V}$ for $40 \mathrm{~min}$ and transferred electrophoretically onto a nitrocellulose membrane (Millipore Corporation) under electrical conditions of $75 \mathrm{~V}$ per membrane for 90 min. The membranes were blocked with PBS containing 5\% nonfat milk powder for $60 \mathrm{~min}$ and incubated with monoclonal primary antibody at $4^{\circ} \mathrm{C}$ overnight. p38, p-p38, and actin protein were detected using a monoclonal antibody (Cell Signaling Technology and Sigma). After washing in PBST (PBS with Tween 20), membranes were incubated in secondary FITC antibody for $120 \mathrm{~min}$ and washed thoroughly again in T-PBS. Membranes were then incubated in tertiary anti-FITC antibody for $60 \mathrm{~min}$ and again washed with T-PBS. Membranes were then placed in enhanced chemiluminescence Western blotting detection reagent (ECF from GE Healthcare) for $10 \mathrm{~min}$. The density of the bands was quantified by using a computerized imaging system (Alpha EaseSC).

ELISA. Peritoneal fluid was harvested from mice by peritoneal lavage after aseptic preparation of the abdominal wall, followed by injection of $9 \mathrm{ml}$ of sterile saline into the peritoneal cavity and aspiration of peritoneal fluid. Serum was collected by cardiac puncture. IL-6, keratinocytederived cytokine (KC), macrophage inflammatory protein-2 (MIP-2), monocytes chemotactic protein-1 (MCP-1), granulocyte colonystimulating factor (G-CSF), and IL-10 levels in the peritoneal fluid and serum were analyzed using ELISA according to the protocol of the manufacturer (IL-6, IL-10 purchased from BioSource International; MCP-1, MIP-2 purchased from PeproTech; KC, G-CSF purchased from R \& D Systems).

Levels of plasma hormones. Plasma insulin and resistin levels were measured by RIA as described previously (López et al., 2006; Nogueiras et al., 2007) using reagents provided in commercial kits (LINCO Research).

Kidney and liver histology. Kidney tissues were fixed in 10\% Formalin and then embedded in paraffin for light microscopy. Sections were stained with hematoxylin and eosin histological examination.

Statistics. Quantitative data are presented as mean \pm SEM. Statistical comparisons were performed using Kaplan-Meier log rank (survival) and Student's $t$ test (two groups). StatView (SAS Institute) and Prism 3.0 (GraphPad Software) were used for statistical analyses. A value of $p \leq$ 0.05 was considered statistically significant.

\section{Results}

\section{Increased sepsis incidence and mortality in human} leptin deficiency

To date, studies in humans have provided evidence for the effects of leptin on T-cell-mediated immune responses. However, in addition, it is notable that, of our patients with congenital leptin deficiency $(n=12)$, four have died of sepsis. Although the precise details of the infectious episode in each case are unknown and there may be additional factors that contribute to the untimely death of these patients, in all of the cases a failure to respond to conventional antimicrobial therapy was reported. We have similarly seen an increased incidence of sepsis and sepsis-related mortality in patients with homozygous loss of function mutations in the leptin receptor ( 5 of the 16 patients have died). However, homozygous mutations in the melanocortin 4 receptor, a downstream target of leptin action in the brain, are not associated with increased sepsis and sepsis-related mortality despite a comparable degree of obesity (no deaths among 16 patients).

\section{Leptin deficiency increases mortality and systemic inflammation in a mouse model of sepsis}

To explore whether leptin controls systemic immune defense mechanisms in a functionally relevant manner, we initially asked whether leptin deficiency affects survival in sepsis by using an established murine model of sepsis (CLP). CLP is a clinically relevant and acceptable model of acute septic peritonitis that has been used to study the systemic response to infection (Wichterman et al., 1980). CLP closely resembles the clinical situation of bowel perforation, inducing peritonitis attributable to mixed intestinal flora.

The survival of leptin-deficient $(o b / o b)$ mice and WT control mice was assessed over a $10 \mathrm{~d}$ period after CLP. $o b / o b$ mice had a higher mortality than wild-type mice $(p=0.0127)$ (Fig. 1a). Indeed, all $o b / o b$ mice died within $72 \mathrm{~h}$ in response to CLP, whereas $30 \%$ of the WT control mice survived that period. Consistent with that observation, the mean survival time was decreased in $o b / o b$ mice $(44.4 \pm 3.8 \mathrm{~h}, n=20, p=0.025)$ compared with WT mice $(66.1 \pm 9.0 \mathrm{~h}, n=17)$. To determine whether increased mortality after CLP in $o b / o b$ mice was secondary to their higher body fat mass, we also assessed survival after CLPinduced sepsis in body weight-matched diet-induced obese (DIO) C57BL/6 mice maintained on a high-fat diet. However, despite a comparably increased body weight as $o b / o b$ mice, the DIO mice had a survival of 55\% within a $10 \mathrm{~d}$ period after CLP. Their survival rate was significantly higher than that of both lean WT mice and $o b / o b$ mice ( $p=0.002$ and 0.028) (Fig. 1a), implying that, if anything, the obesity of $o b / o b$ mice might have been anticipated to help protect them from septic mortality. 

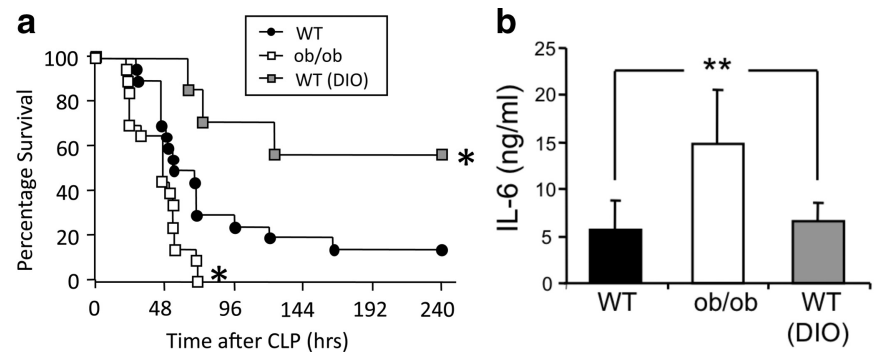

Figure 1. Leptin deficiency contributed to mortality and bacteremia after CLP-induced sepsis. $\boldsymbol{a}$, Survival after CLP in male WT mice $(n=20)$, leptin-deficient $o b / o b$ mice $(n=20)$, and WT mice on high-fat diet (DI0; $n=7)$, monitored for $10 \mathrm{~d}$. The survival curve combines data from one to two independent experiments, each of which gave similar results. ${ }^{*} p<0.05$ compared with the WT control group. $\boldsymbol{b}$, Serum IL- 6 levels $6 \mathrm{~h}$ after CLP ( $n=7-10$ per group) as predictor of mortality and severity of trauma was increased in $o b / 0 b$ mice compared with DI0 mice and WT controls. ${ }^{* *} p<0.01$ compared with the WT control group. c, Bacterial counts were elevated in the blood of the ob/ob mice $24 \mathrm{~h}$ after CLP compared with WT mice $(n=12-13$ per group; data were pooled from 2 independent experiments that gave similar results). CFU, Colony-forming unit. ${ }^{*} p<0.05$ compared with the WT control group. All values are means \pm SEM.

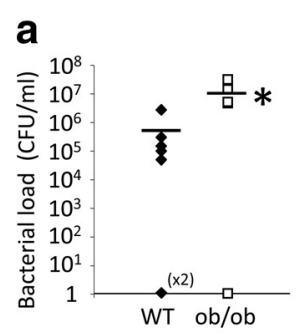

\section{b}

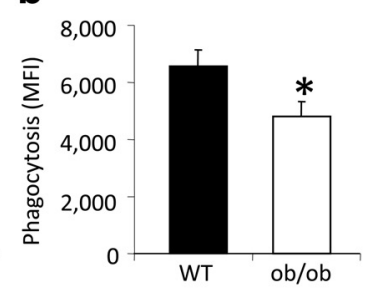

d

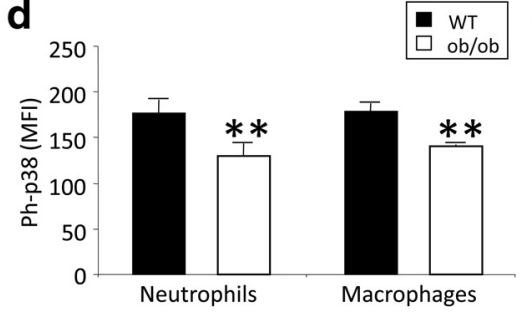

C
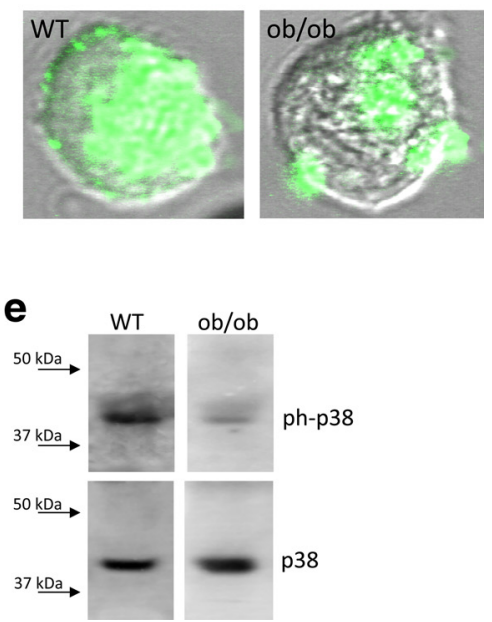

Figure 2. Leptin deficiency increased peritoneal bacterial load and reduced phagocytosis and p38 activation. $\boldsymbol{a}$, Bacterial counts were elevated in the peritoneal lavage of the $o b / 0 b$ mice $24 \mathrm{~h}$ after CLP. Bacterial colony-forming units were calculated in $o b / o b$ and WT mice ( $n=12$ per group; data were pooled from 2 independent experiments that gave similar results). CFU, Colony-forming unit. ${ }^{*} p<0.05$ compared with the WT control group. $\boldsymbol{b}$, Peritoneal neutrophil phagocytosis of opsonized $E$. coli in vitro in ob/ob and WT mice was measured $24 \mathrm{~h}$ after CLP ( $n=14-15$ per group; data were pooled from 2 independent experiments that gave similar results). ${ }^{*} p<0.05$ compared with the WT control group. c, Representative picture of a single neutrophil cell (peritoneal lavage) of each group (WT and $o b / o b$ ) representing the reduced phagocytosis activity in the $o b / o b$ mice compared with the WT controls $24 \mathrm{~h}$ after CLP. $\boldsymbol{d}$, Phosphorylation of p38 MAP kinase of peritoneal neutrophils and macrophages in $0 b / 0 b$ and WT mice was measured $24 \mathrm{~h}$ after CLP using the FACS technique ( $n=5$ per group). ${ }^{* *} p<0.01$ compared with the WT control group. MFI, Mean fluorescence intensity. $\boldsymbol{e}$, Sample of phosphorylated and total p38 MAP kinase in peritoneal cells of $o b / o b$ and WT mice $24 \mathrm{~h}$ after CLP using Western blot technique. All values are means \pm SEM.

Obesity is linked to insulin resistance, and elevated plasma insulin and resistin levels are important surrogate hallmarks of insulin resistance (Emilsson et al., 1997; Rajala et al., 2004). As expected, we found higher circulating insulin and resistin levels in $o b / o b$ mice $(p<0.01)$, but there were no differences in $\mathrm{pH}$, bicarbonate, base deficit, hematocrit, or hemoglobin between $o b / o b$ and WT mice $24 \mathrm{~h}$ after CLP (data not shown). Circulating IL-6 levels are predictive of mortality outcome in human sepsis as well as in the CLP mouse model (Remick et al., 2002). Consistent with our observations on survival, IL-6 was significantly ( $p=$ $0.0005)$ higher in $o b / o b$ mice compared with the WT or the DIO mouse group (Fig. 1b). None of the sham control mice showed increased cytokine levels (data not shown). These data suggest that endogenous leptin may protect against sepsis by modulat-

\section{C}

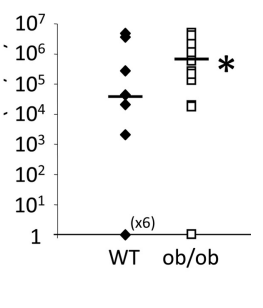

ing proinflammatory agents. Another independent predictor of mortality in sepsis is hypothermia (Pittet et al., 1996). However, $o b / o b$ mice showed a similar drop in core temperature after CLP as WT mice, suggesting that decreased survival in leptin deficiency is unlikely to be a consequence of altered thermogenesis (data not shown). Because the measured systemic levels of the proinflammatory agent IL-6 suggested that leptin may directly promote immune defense against bacteria, we next determined whether $o b / o b$ mice have impaired bacterial clearance. Colony counts of viable bacteria present in blood $24 \mathrm{~h}$ after CLP (Fig. 1c) were more than two orders of magnitude greater in $o b / o b$ mice than in WT mice, whereas no bacteremia was observed in sham-operated mice (data not shown). Moreover, the number of $o b / o b$ mice that developed bacteremia $24 \mathrm{~h}$ after CLP was increased (93\%) relative to WT controls (54\%). These findings are consistent with the decreased survival of $o b / o b$ mice in sepsis and suggest that endogenous leptin signaling modulates systemic inflammatory processes as an essential component of the physiological defense against bacteremia.

\section{Leptin deficiency leads to impaired bacterial clearance at the site of infection in sepsis}

To determine whether the observed systemic involvement of leptin in the control of immune defense is paralleled by local impact at the primary site of infection, bacterial colony counts were made in peritoneal lavage $24 \mathrm{~h}$ after CLP. $o b / o b$ mice had more than two orders of magnitude more colonies than WT controls (Fig. 2a). No bacterial load was detected in sham-operated mice (data not shown). Because neutrophils play a key role in eliminating bacteria (Lee et al., 2003), we next determined whether enhanced mortality and impaired bacterial clearance in leptin deficiency may be attributable to defective neutrophil phagocytosis. Peritoneal neutrophil phagocytosis of opsonized $E$. coli was significantly $(p=0.021)$ reduced in ob/ob mice compared with WT controls (Fig. $2 b, c$ ). However, there were no differences in numbers of neutrophils at the site of infection in $o b / o b$ mice compared with WT controls $24 \mathrm{~h}$ after CLP ( $3.23 \pm 03$ vs $3.02 \pm 0.7, n=7$ per group). These data imply that, although there is no reduction in the number of neutrophils, leptin deficiency may result in loss of neutrophil function at the site of infection. To determine the molecular underpinnings of the decreased neutrophil function, we examined key signal transduction pathways involved in neutrophil function. p38 mitogen-activated protein (MAP) kinase, an essential component of neutrophil function ( $\mathrm{Zu}$ et al., 1998; van den Blink et al., 2004), was significantly reduced in peritoneal neutrophils, i.e., $o b / o b$ mice had a significant reduction of phos- 
phorylated p38 MAP kinase $24 \mathrm{~h}$ after CLP compared with septic WT mice as indicated by FACS ( $n=5$ per group, $>1000$ cells interrogated per group) (Fig. $2 d)$. To corroborate this important finding with a second method, we quantified neutrophil p38 MAP kinase phosphorylation after CLP using Western blot analysis. Consistent with the observations from FACS analysis, septic ob/ob mice had reduced phosphorylated p38 MAP kinase, with no change of total p38 MAP kinase compared with WT controls (Fig. 2e).

Collectively, these data indicate that leptin deficiency contributes substantially to mortality and compromises systemic and local immune responding after CLPinduced sepsis. Neutrophil function, but not neutrophil number, is also diminished in the absence of leptin, and this is reflected by reduced phosphorylation of p38 MAP kinase.

\section{Leptin replacement improves the immune response and reduces organ damage in sepsis}

The enhanced mortality and insufficient immune response of $o b / o b$ mice after CLP could be a consequence of irreversible developmental deficiencies as a result of a lack of leptin during critical periods or alternatively could result from the absence of leptin signaling in sepsis. We therefore asked whether intraperitoneal administration of leptin has a beneficial influence on the immune response in sepsis. Leptin was replaced intraperitoneally in $o b / o b$ and WT mice $(1 \mu \mathrm{g} / \mathrm{g}$ body weight) at 9:00 AM and 6:00 P.M. before and after CLP for a total of four injections before blood, peritoneal lavage and organ harvest. This leptin replacement protocol has been shown to achieve circulating leptin levels (Lord et al., 1998) in the range of serum levels measured in humans (Considine et al., 1996). Replacement of leptin completely normalized IL-6 levels in serum and peritoneal lavage of septic $o b / o b$ mice relative to untreated septic $o b / o b$ and WT mice (Fig. 3a). Leptin administration in sepsis even produced a tendency to decrease IL-6 levels in WT mice compared with untreated WT mice (Fig. 3a). The anti-inflammatory cytokine IL-10 is an inhibitor of T-cell-, monocyte-, and macrophage function. It limits and ultimately terminates inflammatory responses (Moore et al., 2001) and enhances the function of natural killer cells (Mocellin et al., 2003). IL-10 levels, however, did not differ between septic $o b / o b$ and WT mice with or without leptin administration (Fig. 3b), suggesting that leptin regulates some but not all inflammatory processes.

To determine whether modulation of inflammatory processes by leptin also affects sepsis-induced tissue damage, we measured BUN concentration, a surrogate parameter of kidney damage, $24 \mathrm{~h}$ after CLP. ob/ob mice had significantly higher BUN levels than the WT group ( $p=0.001$ ) (Fig. $3 c$ ), and the number of ob/ob mice that developed a BUN level higher than $75 \mathrm{mg} / \mathrm{dl}$ (as a critical sign of acute renal failure) was also increased (10 of 13; $77 \%$ ) relative to WT controls ( 4 of $14 ; 29 \%$ ). Leptin administration normalized mean BUN levels and reduced the number of mice with acute renal failure (2 of $8 ; 25 \%)$ in both $o b / o b$ and WT mice.

We corroborated these indirect findings with histopathological examination of the kidney in $o b / o b$ and WT mice $24 \mathrm{~h}$ after CLP (Fig. 3d). After CLP, ob/ob mice exhibited enhanced swelling of the cortical tubules, diffuse vacuolar degeneration, and focal tubular necrosis, as well as a slightly increased cast formation compared with WT mice. Treatment with leptin decreased cast formation of the cortical tubules and lowered vacuolar degeneration as well as focal necrosis, without much impact on tubular swelling (Fig. 3d). In leptin-treated WT mice, the diffuse degeneration and focal necrosis of the tubular epithelium (proximal as well as distal tubules) appeared to be less extensive, whereas tubular swelling and degeneration was still present (Fig. $3 d$ ). Overall, these results indicate that leptin protects against cellular kidney damage in sepsis, at least to some extent.

To examine the level of liver damage after CLP, we measured ALT, a serum marker of liver cell damage (Amacher, 2002; Ozer et al., 2008), 24 h after CLP. ob/ob mice had significantly higher ALT levels than the WT group, reflecting more liver damage $(p<$ 0.05; data not shown). We assessed liver histology in the same mice and found that hydropic degeneration and focal necrosis of hepatocytes was more severe in $o b / o b$ mice than WT controls (data not shown).

Beneficial effects of leptin administration in CLP-induced sepsis could theoretically be a secondary consequence of the well known catabolic action of the hormone, including reduced body weight. In none of these acute experiments, however, did body weights differ between acutely leptin-treated mice and control mice at any time point (data not shown). In summary, these 
a

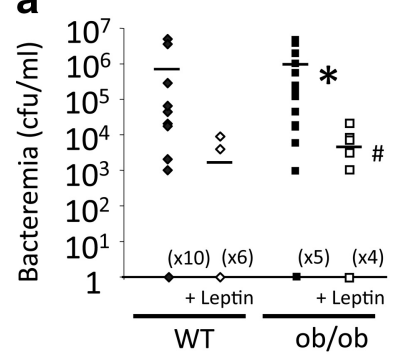

b

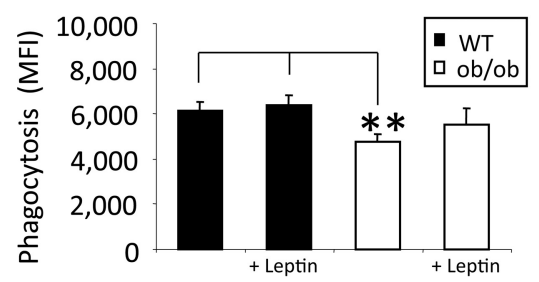

C

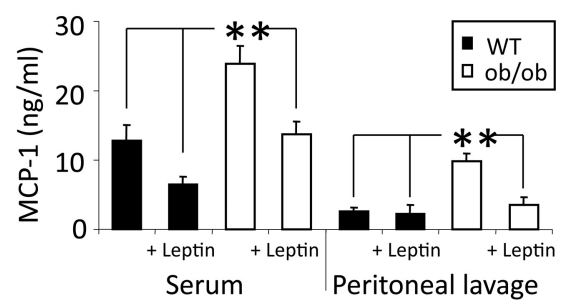

d

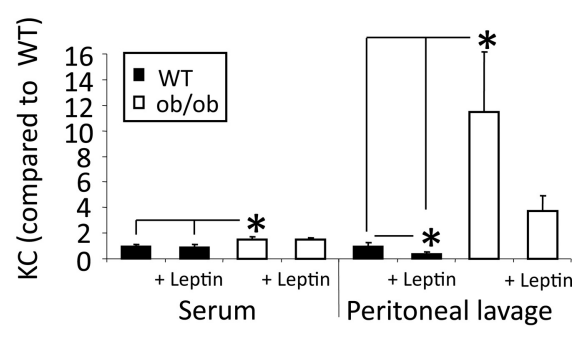

e

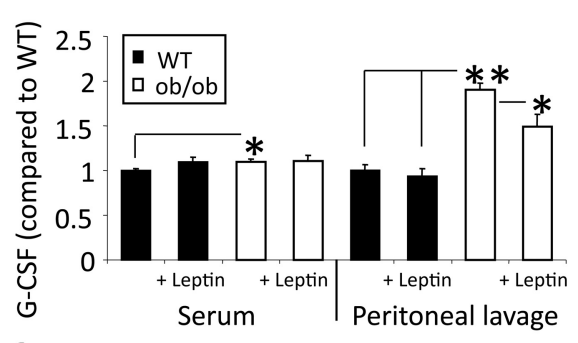

f

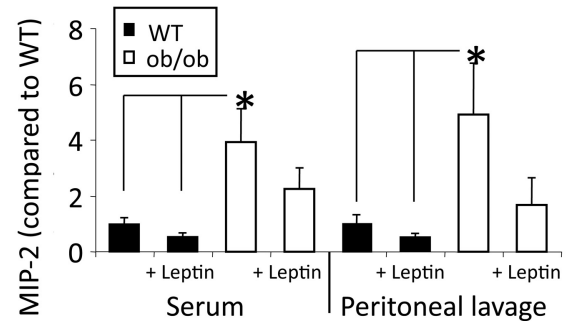

Figure 4. Leptin replacement showed beneficial effects on bacteremia, phagocytosis, and cytokine levels after CLP. $\boldsymbol{a}$, After leptin replacement ( $1 \mu \mathrm{g} / \mathrm{g}$ body weight, i.p., twice per day) bacterial counts in the blood were reduced in both WT and $0 b / 0 b$ mice $24 \mathrm{~h}$ after CLP ( $n=8-21$ per group; data were pooled from 2 to 4 independent experiments that gave similar results). CFU, Colony-forming unit. ${ }^{*} p<0.05$ compared with the WT group; ${ }^{\#} p<0.05$ compared with the untreated ob/ob group. $\boldsymbol{b}$, Peritoneal neutrophil phagocytosis of opsonized $E$. coli in vitro after leptin reconstitution ( $1 \mu \mathrm{g} / \mathrm{g}$ body weight, i.p.). Phagocytosis in $0 b / 0 b$ was increased after leptin reconstitution compared with the untreated $0 b / 0 b$ mice $24 \mathrm{~h}$ after CLP ( $n=8-16$; data were pooled from 2 independent experiments that gave similar results). ${ }^{*} p<0.05$ and ${ }^{* *} p<0.01$ compared with both WT groups. MFI, Mean fluorescence intensity. $\mathbf{c}-\mathbf{f}$, WT and ob/ob mice with leptin (or saline as control) replacement ( $1 \mu \mathrm{g} / \mathrm{g}$ body weight, i.p.) underwent CLP. MIP-2, KC, MCP-1, and G-CSF levels (nanograms per milliliter or $x$-fold of WT CLP values) were measured in both serum and peritoneal lavage $24 \mathrm{~h}$ after CLP. Leptin deficiency resulted in a significant increase of all chemokine levels and decreased to WT levels by leptin replacement ( $1 \mu \mathrm{g} / \mathrm{g}$ body weight, i.p.; data are 1 representative experiment of $2-3$ independent experiments). ${ }^{*} p<0.05$ and ${ }^{* *} p<0.01$ compared with the WT control group and the leptin-treated group. All values are means \pm SEM.

replacement in $o b / o b$ mice suggests that endogenous leptin controls neutrophil clearing of bacteria.

To further dissect the molecular underpinnings of this observation, we screened plasma and peritoneal lavage fluid for MCP-1, KC, MIP-2, and G-CSF. These chemokines are pivotal in the recruitment and activation of neutrophils and monocytes (Kurihara et al., 1997; Czuprynski et al., 1998). The expression of MIP-2 and $\mathrm{KC}$ [both powerful chemoattractants for, and activators of, neutrophils (Chensue, 2001)], MCP-1 [monocyte activation and recruitment to the site of infection (Adams and Lloyd, 1997; Lu et al., 1998)], and G-CSF [stimulation of development of progenitors to neutrophils and enhancement of neutrophilic functional activity and differentiation (Nagata et al., 1986; Kamezaki et al., 2005)] in serum and peritoneal lavage were determined $24 \mathrm{~h}$ after CLP. ob/ob mice had significantly higher levels of each of these chemokines in both serum and peritoneal lavage relative to septic WT controls (Fig. $4 c-f$ ). Administration of leptin to $o b / o b$ mice reduced chemokine levels nearly to the levels seen in WT serum and peritoneal lavage. Leptin administration in WT mice resulted in no change or a slight decrease of chemokine levels relative to the untreated WT group. Interestingly, elevated MCP-1 levels in $o b / o b$ mice was not associated with increased numbers of monocytes at the site of infection. In both WT and ob/ob mice, leptin administration did not change monocyte counts $24 \mathrm{~h}$ after CLP (data not shown). Together, these results suggest that leptin potently regulates neutrophil function via modulation of several specific chemokines. findings indicate that leptin action appears to reduce the IL-6 response, seems to decrease hepatic markers of liver damage, and may reduce renal damage in sepsis.

Systemic leptin administration improves neutrophil function and increases bacterial clearance

Bacterial colony counts were significantly $(p=0.03)$ lower in leptin-treated than untreated ob/ob mice $24 \mathrm{~h}$ after CLP (Fig. $4 a$ ). Leptin treatment of WT mice also decreased bacterial counts compared with saline-injected WT controls. In control experiments, no bacteremia was observed in sham mice (data not shown). To determine whether the reduced bacterial burden after leptin administration was associated with improved phagocytosis, we compared peritoneal neutrophil phagocytosis of opsonized E. coli in vitro. As depicted in Figure $4 b$, phagocytosis of $E$. coli in sepsis was increased in $o b / o b$ mice with leptin replacement $(21 \%)$ compared with levels in untreated ob/ob mice. Septic WT mice had only a slight increase in phagocytosis (10\%) after leptin administration. The enhanced phagocytosis observed after leptin
Leptin administration directly into the CNS increases survival of septic $o b / o b$ mice

The experiments on loss-of-function and gain-of-function described above indicate that endogenous leptin controls systemic inflammation and immune defense to the extent that leptin signaling promotes survival and prevents organ damage in sepsis. However, the organ specificity of essential leptin receptor activation remains unclear. Numerous studies on the role of leptin in metabolism and reproductive biology have shown that action of leptin in the CNS is sufficient to fulfill almost all of its physiological functions. To determine whether the role of leptin in the control of immune defense follows a similar paradigm, we implanted intracerebroventricular minipumps containing leptin (1 $\mu \mathrm{g} / 24 \mathrm{~h}$ ) or vehicle (saline, $1 \mu \mathrm{g} / 24 \mathrm{~h}$ ) into $o b / o b$ mice before CLP. Leptin replacement into the CNS of $o b / o b$ mice increased survival rates significantly ( $p=0.027$ ) relative to vehicle-infused $o b / o b$ controls (Fig. 5a). Leptin administration into the CNS also significantly decreased serum IL-6 of septic $o b / o b$ mice relative to untreated septic ob/ob $24 \mathrm{~h}$ after CLP ( $p=0.028$ ) (Fig. $5 b)$ but 
did not change serum IL-10 (Fig. 5c), suggesting that leptin regulates selected inflammatory processes. Intracerebroventricular leptin-treated ob/ob mice also had significantly reduced BUN ( $p=0.044)$ compared with controls (Fig. $5 d$ ), indicating that CNS leptin can ameliorate sepsis-induced kidney damage. Systemic MCP-1 and KC levels were also significantly reduced in CNS leptin-treated mice ( $p=0.017$ and 0.023 ) (Fig. 5e,f). To rule out the possibility that a fraction of the small amount of intracerebroventricularly infused leptin escaped into the periphery and reached immune-relevant targets via the circulation, we infused the same amount of leptin systemically using peripherally implanted minipumps, and there was no improvement in survival or immune parameters after CLP (Fig. 6). These findings therefore demonstrate for the first time that leptin administration directly into the CNS influences survival and the immune response to sepsis in a beneficial manner. To ensure that the beneficial effects of leptin on immune response and survival in sepsis are not just a consequence of altered systemic corticosterone levels, we performed an additional experiment in which we chronically infused intracerebroventricular leptin and measured food intake, body weight, and corticosterone levels in mice. Seven days of intracerebroventricular leptin infusion $(1.0 \mu \mathrm{g} / \mathrm{d})$ decreased daily food intake and body weight but did not alter circulating corticosterone levels significantly in C57B6/J and ob/ob mice (Fig. $7 a-d$ ). Together, these data show that the increase in survival of leptin-treated mice was not mediated via generation of corticosterone.

\section{Genetic rescue of leptin signaling in the CNS normalizes decreased survival of $d b / d b$ mice}

Pharmacological administration of leptin directly into the CNS of $o b / o b$ mice rescues their survival in sepsis. To corroborate that finding, we used a genetic approach to test whether endogenous CNS leptin action controls survival in sepsis. Specifically, we tested whether survival of globally leptin receptor-deficient $(d b /$ $d b)$ mice in sepsis would still differ from survival of WT littermates if leptin signaling was genetically reinstated exclusively in the brain. To rescue CNS leptin signaling only, we used NSE-cre and Lepr ${ }^{\text {flox/ }}$ flox mice (Kowalski et al., 2001; Chua et al., 2004; de Luca et al., 2005). We compared these mice (which only have functioning leptin receptor signaling in the CNS but not in any peripheral organs) with $d b / d b$ mice (which have no leptin receptor signaling at all) and WT control mice. Survival of $d b / d b$ mice with rescued leptin signaling in CNS neurons, which were however still lacking any leptin receptors in peripheral, specifically immunecompetent, cells, did not differ from survival of WT littermates ( $p=0.18)$. However, these mice showed markedly increased survival compared with $d b / d b$ mice ( $p=0.0001$ ) (Fig. 6). These observations were strikingly consistent with our pharmacological studies and confirmed that endogenous leptin signaling in the CNS is critical for normal survival rates in sepsis.

\section{Leptin administration into the CNS increases survival in WT mice}

Restoring normal immune function to animals lacking leptin from birth is highly important and reveals a previously unknown

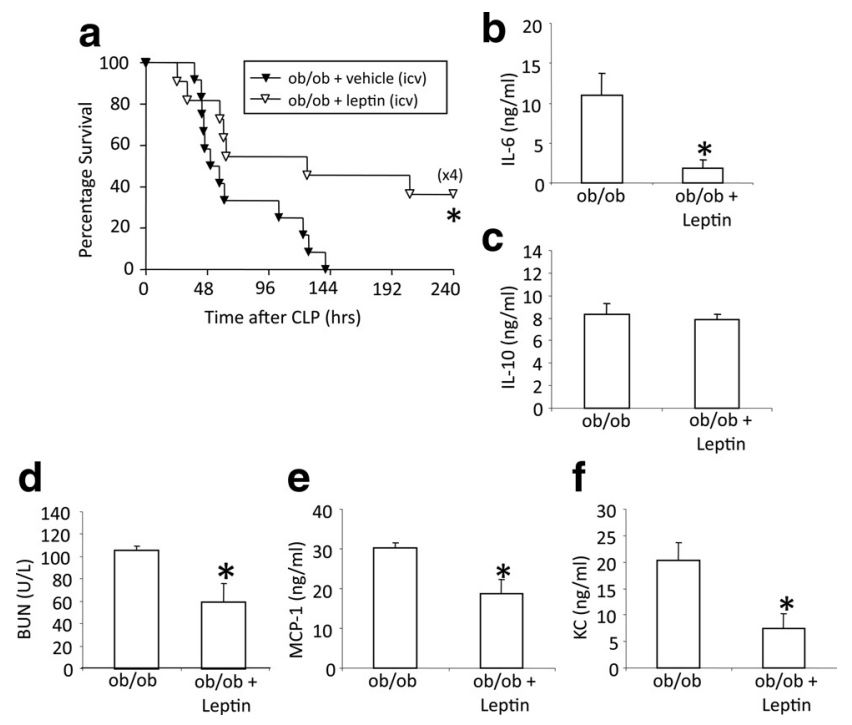

Figure 5. Leptin treatment in the CNS increased survival and systemic inflammatory response in $o b / o b$ mice. $\boldsymbol{a}, o b / o b$ mice with vehicle (via intracerebroventricular catheter with minipumps, $1 \mu \mathrm{g} / 24 \mathrm{~h})(n=13)$ and ob/ob mice with leptin (intracerebroventricular minipumps) ( $n=11$ ) underwent (LP and were monitored for survival for $10 \mathrm{~d}$. Data were pooled from two independent experiments that gave similar results. ${ }^{*} p<0.05$ compared with the untreated $o b / o b$ group. $\boldsymbol{b}, \boldsymbol{c}, o b / o b$ mice with leptin treatment in the CNS underwent CLP. IL-6 and IL-10 levels (both nanograms per milliliter) were measured in serum $24 \mathrm{~h}$ after CLP. Leptin treatment resulted in a significant decrease of systemic IL-6 levels but no changes of systemic IL-10 levels ( $n=4-5$ per group). ${ }^{*} p<0.05$ compared with the untreated ob/ob group. $\boldsymbol{d}$, Blood urea nitrogen (BUN) was measured $24 \mathrm{~h}$ after (LP in serum. Leptin treatment in the CNS resulted in decreased BUN levels ( $n=4-5$ per group). ${ }^{*} p<0.05$ compared with the untreated ob/ob group. $\boldsymbol{e}, \boldsymbol{f}, o b / o b$ mice with leptin treatment in the CNS underwent CLP. MCP-1 and KC levels (both nanograms per milliliter) were measured in serum $24 \mathrm{~h}$ after CLP. Leptin treatment resulted in a significant decrease of systemic MCP- 1 and KC levels $(n=4-5$ per group). ${ }^{*} p<0.05$ compared with the untreated ob/ob group. All values are means \pm SEM.
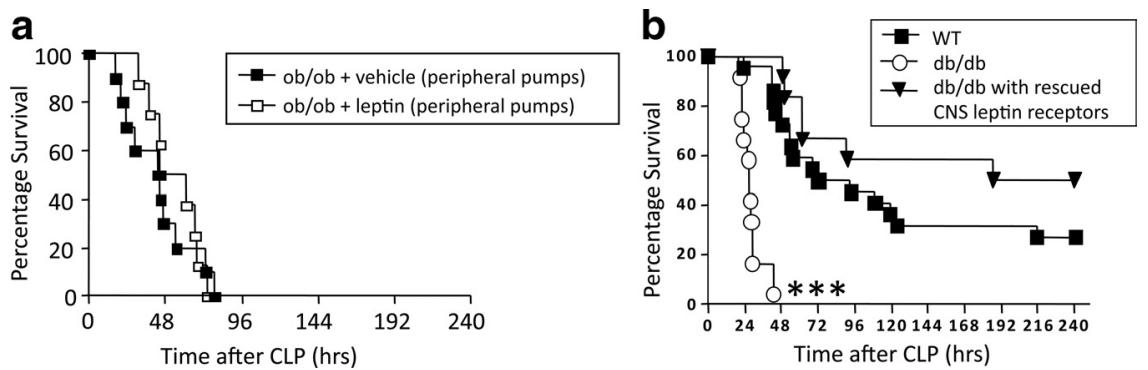

Figure 6. Peripheral administration of low-dose leptin does not affect survival after CLP, whereas rescued leptin signaling specifically in CNS is sufficient for normal survival rates in sepsis. $\boldsymbol{a}, o b / o b$ mice with vehicle (via peripheral minipumps, $1 \mu \mathrm{g} / 24 \mathrm{~h}$ ) $(n=10)$ and $o b / o b$ mice with leptin (peripheral minipumps) $(n=10)$ underwent CLP and were monitored for survival for $10 \mathrm{~d}$ b, Survival of $d b / d b$ mice, $d b / d b$ mice with rescued leptin signaling in CNS neurons, and WT littermates ( $n=10-12$ per group). Age-matched mice underwent CLP and were monitored for survival until all animals dies. ${ }^{* * *} p<0.01$ compared with $d b / d b$ animals.

function of this systemic cytokine. However, it cannot be inferred from those experiments whether a low level of leptin in the CNS has a permissive role or whether incrementing leptin action in normal animals would bestow a similar benefit. To assess this, we implanted intracerebroventricular minipumps containing leptin $(1 \mu \mathrm{g} / 24 \mathrm{~h})$ or vehicle (saline as control) into WT mice $3 \mathrm{~d}$ before performing CLP. Leptin increased survival rates relative to vehicle-infused controls (Fig. 8a). These unexpected findings were paralleled by changes in systemic immune parameters. Leptin administration into the CNS significantly decreased $(p=$ 0.016 ) serum IL-6 in septic WT mice (Fig. $8 b$ ), and there was no 
a

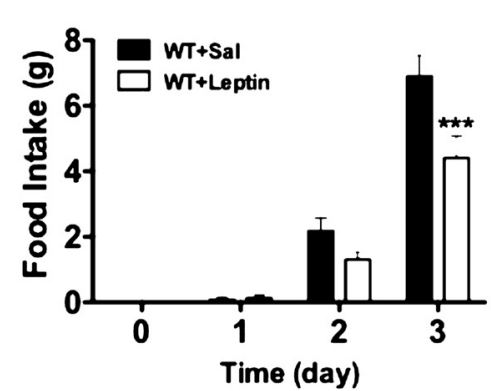

C
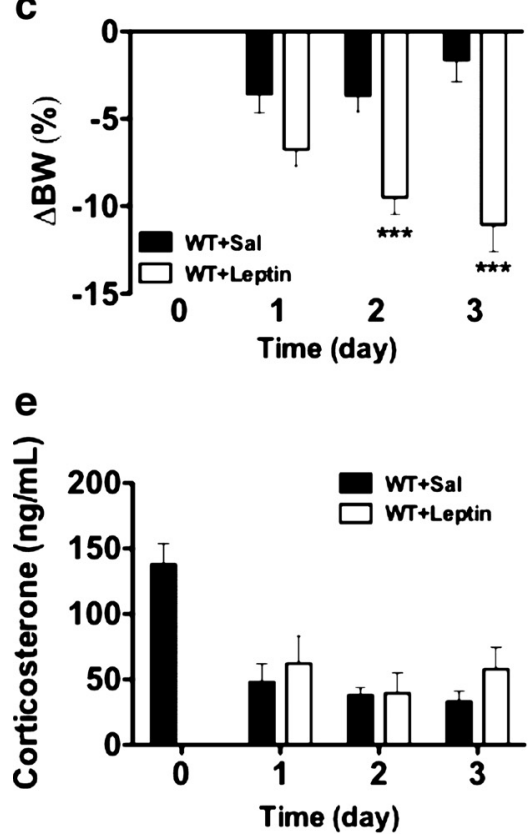

b

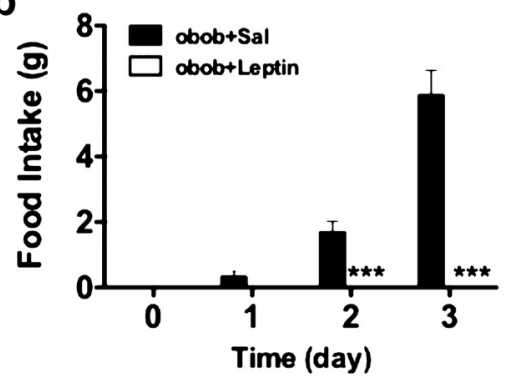

d

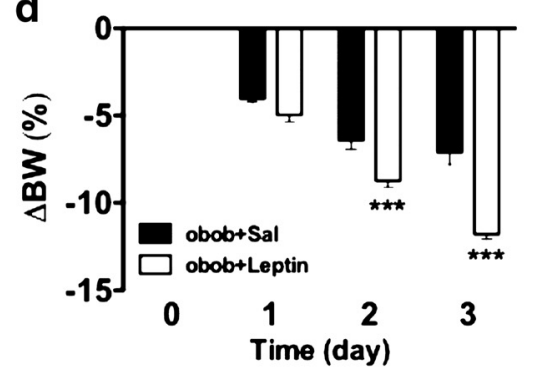

f

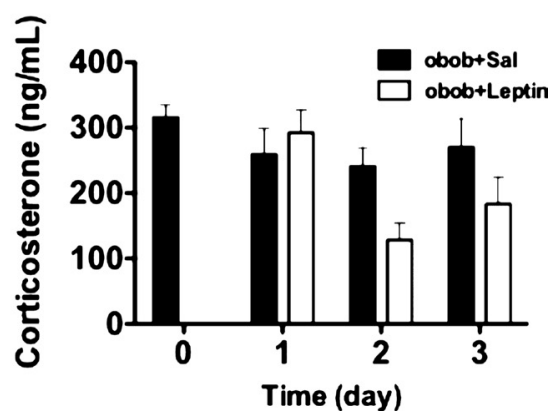

Figure 7. Intracerebroventricular infusion of low-dose leptin does not affect systemic corticosterone levels in WT or ob/ob mice. $\boldsymbol{a}-\boldsymbol{f}$, Effect of a $7 \mathrm{~d}$ intracerebroventricular leptin $(1.0 \mu \mathrm{g} / \mathrm{d})$ infusion on daily food intake $(\boldsymbol{a}, \boldsymbol{b})$, body weight change $(\boldsymbol{c}, \boldsymbol{d})$, and corticosterone levels $(\boldsymbol{e}, \boldsymbol{f})$ in C57B6/J and ob/ob mice. ${ }^{* * *} p<0.001$. BW, Body weight; Sal, saline.

change of IL-10 (Fig. 8c). Consistent with the lack of change of BUN in septic WT mice given systemic leptin (Fig. $3 c$ ), intracerebroventricular leptin also did not affect BUN (Fig. 8d). Interestingly, systemic MCP-1 and KC levels were significantly reduced in intracerebroventricular leptin-treated WT mice compared with the untreated septic WT mice $(p=0.05$ and 0.03$)$ (Fig. $8 e, f$ ).

These data reveal that a specific CNS pathway controls systemic immune responses in a functionally relevant manner, conferring protection against sepsis. Specifically, leptin signaling in the CNS is required for efficient coordination of this CNScontrolled immune response in sepsis and is crucial to limit organ damage and prevent mortality, and incrementing leptin in the brain of normal animals enhances their ability to cope with sepsis.

\section{Discussion}

The observations presented here reveal the existence of a specific CNS signaling system that controls systemic immune defense in a functionally relevant manner. This conclusion is based on a combination of pharmacological and genetic models and indicates that CNS leptin action is part of an important regulatory system controlling systemic immune defense. We observed that leptin deficiency is associated with an impaired immune response and lowered survival in a murine model of sepsis. Interestingly, leptin deficiency seems to specifically weaken neutrophil function by inhibition of p38 MAP kinase activation. Systemic leptin replacement corrects the immune response, but, most importantly, pharmacological increase or genetic rescue of leptin signaling exclusively and specifically within the CNS is sufficient to improve mortality and cytokine profiles in sepsis. The beneficial effects of leptin that is directly administered into the CNS do not result from leakage of leptin to the periphery in that $o b / o b$ mice, which were infused with the same low dose of leptin peripherally, were not improved (Fig. 6). In contrast, higher doses of peripherally administered leptin in $o b / o b$ mice were sufficient to modulate various important immune functions (Figs. 3, 4) and are likely to achieve those effects by crossing the blood-brain barrier and acting at CNS leptin receptors. It seems intriguing that leptin receptordeficient $d b / d b$ mice seem to show reduced survival although presumably leptin resistant DIO mice do not. One potential explanation for the difference in survival may be that $d b / d b$ mice are completely leptin receptor deficient, whereas in DIO mice, the level of leptin receptor desensitization in response to chronic high-fat diet exposure may be partial or tissue specific.

A considerable body of previously published observations suggest that leptin may regulate immune function (Lam and Lu, 2007) presumably via modulation of the autonomic nervous system. Mancuso and colleagues reported that leptin deficiency leads to weakened immune defense in mouse models of pneumonia and that leptin replacement provides benefits for the host defense in these models (Mancuso et al., 2002, 2006; Hsu et al., 2007). Other studies observed a weakened defense of leptin-deficient mice against mycobacterium tuberculosis and lipopolysaccharides (Faggioni et al., 1999; Wieland et al., 2005) as well as hepatic effects of listeria infection (Ikejima et al., 2005). Some of the first studies revealing a potential role of leptin in the modulation of immune function were reported by Lord et al. (1998) who demonstrated that declining leptin levels may be responsible for the diminished immune response in starvation. These observations were consistent with evidence generated decades before leptin was discovered that leptin ( $o b / o b$ mice) or leptin receptor deficiency $(d b / d b$ mice) is associated with reduced T-cell function (Mandel and Mahmoud, 1978). However, all of these previous studies focused exclusively on putative peripheral effects of leptin, for example, via leptin receptors on lymphocytes or macrophages (Gainsford et al., 1996; Caldefie-Chezet et al., 2001; Siegmund et al., 2004).

The resolution to a bacterial infection includes an immune response that contains and eliminates the pathogen. In contrast, a dysfunctional response allows for the systemic spread of bacteria and increased tissue damage. Our data suggest that leptin is an important contributor to that functional immune response to a septic challenge. In support of this, we observed that phagocytic 

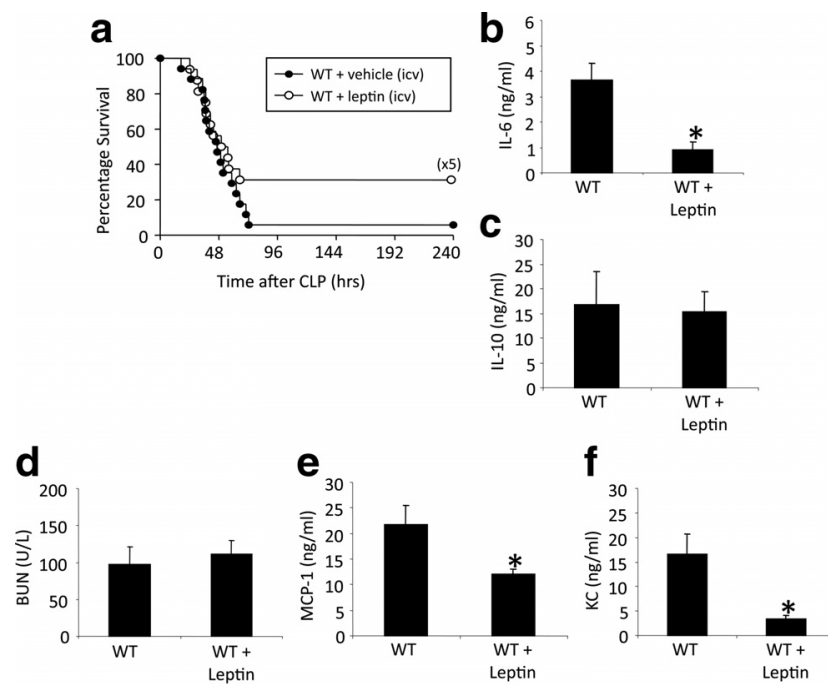

Figure 8. Leptin treatment in the CNS increased survival and systemic inflammatory response in WT mice. $\boldsymbol{a}$, WT mice with vehicle (intracerebroventricular pumps) ( $n=18$ ) and WT mice with leptin (intracerebroventricular pumps) $(n=16)$ underwent CLP and were monitored for survival for $10 \mathrm{~d}$. Data were pooled from two independent experiments that gave similar results. $\boldsymbol{b}, \boldsymbol{c}$, WT mice with leptin treatment in the CNS underwent CLP. IL-6 and IL-10 levels (both nanograms per milliliter) were measured in serum $24 \mathrm{~h}$ after CLP. Leptin treatment resulted in a significant decrease of systemic IL-6 levels but no changes of systemic IL-10 levels ( $n=4-5$ per group). ${ }^{*} p<0.05$ compared with the untreated WT group. $\boldsymbol{d}$, BUN was measured $24 \mathrm{~h}$ after CLP in serum. Leptin treatment in the CNS showed no changes of BUN levels in WT mice ( $n=4-5$ per group). $\boldsymbol{e}, \boldsymbol{f}$, WT mice with leptin treatment in the CNS underwent CLP. MCP-1 and KC levels (both nanograms per milliliter) were measured in serum $24 \mathrm{~h}$ after CLP. Leptin treatment resulted in a significant decrease of systemic MCP-1 and KC levels ( $n=4-5$ per group). ${ }^{*} p<0.05$ compared with the untreated WT group. All values are means \pm SEM.

activity was suppressed in neutrophils taken from septic leptindeficient mice (Fig. 2b). We speculate that the increased bacterial load at the site of infection in the leptin-deficient mice was primarily caused by this decreased phagocytosis. Furthermore, increased bacterial load at the site of infection leads to increased inflammation, resulting in increased tissue permeability (Schlag et al., 1991; Tschöp et al., 2008). This would allow the pathogen to spread to the blood and organs. Among many actions in response to bacteria, tissues secrete chemokines. We further speculate that the increased serum KC and MIP-2 isolated from the leptindeficient mice was caused by the larger bacterial spread that was observed. Finally, we observed that neutrophils isolated from leptin-deficient mice had decreased neutrophil p38 activation. The p38 MAP kinase is involved in an intracellular kinase cascade that regulates stress-activated signal transduction. In response to certain stresses, such as sepsis or proinflammatory cytokines, p38 MAP kinase becomes activated. Zu et al. (1998) have found that p38 MAP kinase is required for neutrophil function in humans. Leptin is capable of inducing neutrophil locomotion by activation of p38 MAP kinase (Montecucco et al., 2006). Loss of p38 MAP kinase activation may represent an important mechanism responsible for proper neutrophil function such that tissue damage is increased.

Using a murine sepsis model along with selective pharmacological and genetic modulation of CNS leptin signaling, we have demonstrated that the essential impact of leptin on immune defense mechanisms is mediated in the brain. We find that CNS leptin action improves survival, normalizes the response of chemokines IL-6, MCP-1, and KC to CLP-induced immune challenge, and decreases BUN levels reflecting less organ damage. In principle, non-immune-specific actions of leptin could have contributed to our observations. However, with our study design, we did not find thermoregulatory differences between treatment groups or differences in body weight, although there were contemporaneous effects on immune function. One theoretical possibility for a nonspecific action of leptin to contribute to its impact on immune function would be via its known role in the modulation of the hypothalamus-pituitary-adrenal (HPA) axis: $o b / o b$ mice have increased circulating levels of corticosterone, which would suppress immune function. Systemic or peripheral leptin administration would act to normalize the HPA axis activity and thereby potentially promote immune function. However, intracerebroventricular leptin administration actually decreases secretion of cytokines and chemokines, such as IL-6, MCP-1, and $\mathrm{KC}$, and improves survival, even in WT mice, which have normal corticosterone levels and adrenal function. We therefore propose that leptin acts in the brain to directly regulate peripheral immune function and thereby contribute better outcomes in infectious diseases or sepsis compared with states of relative or total leptin deficiency. A CNS leptin-induced enhancement of systemic immune defense may be mediated by ANS signaling as suggested by studies focusing on cholinergic modulation of inflammatory pathways in sepsis (Tracey, 2007) and the known impact of CNS leptin action on peripheral metabolism via the efferent ANS. Based on this model, we consider it likely that large amounts of peripherally administered leptin cross the blood-brain barrier (Banks, 2006) via active transport to achieve its effects on the immune system by acting in the CNS and affecting peripheral immune defense components via modulation of the ANS.

It has become clear from recent studies that stroke-induced or traumatic CNS injury leads to secondary immunodeficiency and significantly increases susceptibility to infection based on brainspecific mechanisms (Prass et al., 2003; Dziedzic et al., 2004; Meisel et al., 2005; Dirnagl et al., 2007). Understanding CNS injury-induced immunodepression (CIDS) may set the stage for the development of novel effective therapeutic strategies for eliminating a major determinant of mortality after CNS damage (Meisel et al., 2005). We speculate that lack of leptin action in the CNS may represent one important component of the molecular mechanisms leading to CIDS and that leptin analogs may offer potential pharmacological opportunities for the treatment of sepsis. Future studies will have to identify and dissect the likely complex neural circuitry and efferent connections specifically mediating central effects of leptin on systemic immune defense, thereby providing the basis for a new understanding of CIDS.

The concept of a specific and functionally relevant CNS control of peripheral immune defense, as implied by the present results, is consistent with a series of observations reported by Tracey (2007). Tracey examined the role of the ANS in the regulation of immunity and have proposed the existence of a brainbased control of the inflammatory response to sepsis. In Tracey's model, the ANS detects the presence of inflammatory stimuli and in return modulates cytokine production as documented by pharmacological and electrophysiological studies. The vagus nerve communicates afferent signals to the brain as well as responsive efferent activity culminating in the release of acetylcholine (ACh) affecting macrophages via macrophage $\alpha 7$ subunits of nicotinic ACh receptors, and this in turn leads to decreased cytokine release (Wang et al., 2003). Autonomic dysfunction has been associated with human inflammatory diseases such as diabetes and sepsis, suggesting that these diseases may actually be caused 
or exacerbated by an autonomic dysfunction. Interestingly, afferent as well as efferent vagal signaling has been shown to mediate components of leptin action (Nagashima et al., 2000; Buyse et al., 2001; Peters et al., 2006a,b; Williams et al., 2007). Although we are confident based on the available data that the autonomic nervous system plays a considerable role in the neuroendocrine control of systemic immune function and survival in sepsis, it is well known that leptin can modulate the activity of the HPA axis. We therefore performed additional experiments in which we were able to show that, with the doses infused intracerebroventricularly in our series of studies, no significant change in circulating corticosterone levels was caused. Therefore, it seems unlikely that our findings are a consequence of leptin-induced HPA axis modulation.

Consistent with these preclinical data, the observation that several patients with congenital leptin and leptin receptor deficiency have died of sepsis suggests the clinical relevance of these findings. Further supporting the clinical relevance of our findings, it was recently reported that relatively low leptin in patients with sepsis is correlated with high mortality (Bracho-Riquelme et al., 2008). These clinical observations, together with our studies indicating that leptin treatment improves immune function and survival even in WT mice, which are not genetically leptin deficient, strongly supports a potential therapeutic value for leptin and its analogs in the treatment of sepsis and related disorders.

The role of leptin in the control of the immune response via the CNS has not been described previously. Here, we show that leptin is a critical factor in host resistance and that the lack of leptin contributes substantially to mortality and weakens systemic and local immune responding as an essential component of the physiological defense against bacteremia after CLP, a model of severe sepsis. Sepsis-induced organ damage is increased whereas neutrophil function is diminished by attenuation of $\mathrm{p} 38$ MAP kinase signaling. We further describe an important role of leptin in the CNS for regulating survival and systemic immune response in sepsis: selective leptin administration into the CNS controls systemic immune response in a functionally relevant manner and to the extent of significant protection from sepsis. We conclude that leptin-dependent neurocircuitry in the CNS is required for efficient coordination of the immune response in sepsis to limit organ damage and prevent mortality.

\section{References}

Adams DH, Lloyd AR (1997) Chemokines: leucocyte recruitment and activation cytokines. Lancet 349:490-495.

Amacher DE (2002) A toxicologist's guide to biomarkers of hepatic response. Hum Exp Toxicol 21:253-262.

Banks WA (2006) Blood-brain barrier and energy balance. Obesity 14 [Suppl 5]:234S-237S.

Barash IA, Cheung CC, Weigle DS, Ren H, Kabigting EB, Kuijper JL, Clifton DK, Steiner RA (1996) Leptin is a metabolic signal to the reproductive system. Endocrinology 137:3144-3147.

Blüher S, Mantzoros CS (2007) Leptin in reproduction. Curr Opin Endocrinol Diabetes Obes 14:458-464.

Bracho-Riquelme RL, Reyes-Romero MA, Pescador N, Flores-García AI (2008) A leptin serum concentration less than $10 \mathrm{ng} / \mathrm{ml}$ is a predictive marker of outcome in patients with moderate to severe secondary peritonitis. Eur Surg Res 41:238-244.

Buyse M, Ovesjö ML, Goïot H, Guilmeau S, Péranzi G, Moizo L, Walker F, Lewin MJ, Meister B, Bado A (2001) Expression and regulation of leptin receptor proteins in afferent and efferent neurons of the vagus nerve. Eur J Neurosci 14:64-72.

Caldefie-Chezet F, Poulin A, Tridon A, Sion B, Vasson MP (2001) Leptin: a potential regulator of polymorphonuclear neutrophil bactericidal action? J Leukoc Biol 69:414-418.
Campfield LA, Smith FJ, Guisez Y, Devos R, Burn P (1995) Recombinant mouse $\mathrm{OB}$ protein: evidence for a peripheral signal linking adiposity and central neural networks. Science 269:546-549.

Chehab FF, Lim ME, Lu R (1996) Correction of the sterility defect in homozygous obese female mice by treatment with the human recombinant leptin. Nat Genet 12:318-320.

Chehab FF, Mounzih K, Lu R, Lim ME (1997) Early onset of reproductive function in normal female mice treated with leptin. Science 275:88-90.

Chensue SW (2001) Molecular machinations: chemokine signals in hostpathogen interactions. Clin Microbiol Rev 14:821-835, table of contents.

Chua SC Jr, Liu SM, Li Q, Sun A, DeNino WF, Heymsfield SB, Guo XE (2004) Transgenic complementation of leptin receptor deficiency. II. Increased leptin receptor transgene dose effects on obesity/diabetes and fertility/lactation in lepr-db/db mice. Am J Physiol Endocrinol Metab 286:E384-E392.

Considine RV, Sinha MK, Heiman ML, Kriauciunas A, Stephens TW, Nyce MR, Ohannesian JP, Marco CC, McKee LJ, Bauer TL (1996) Serum immunoreactive-leptin concentrations in normal-weight and obese humans. N Engl J Med 334:292-295.

Czuprynski CJ, Brown JF, Steinberg H, Carroll D (1998) Mice lacking the murine interleukin-8 receptor homologue demonstrate paradoxical responses to acute and chronic experimental infection with Listeria monocytogenes. Microb Pathog 24:17-23.

Czura CJ, Tracey KJ (2005) Autonomic neural regulation of immunity. J Intern Med 257:156-166.

de Luca C, Kowalski TJ, Zhang Y, Elmquist JK, Lee C, Kilimann MW, Ludwig T, Liu SM, Chua SC Jr (2005) Complete rescue of obesity, diabetes, and infertility in $\mathrm{db} / \mathrm{db}$ mice by neuron-specific LEPR-B transgenes. J Clin Invest 115:3484-3493.

De Rosa V, Procaccini C, La Cava A, Chieffi P, Nicoletti GF, Fontana S, Zappacosta S, Matarese G (2006) Leptin neutralization interferes with pathogenic $\mathrm{T}$ cell autoreactivity in autoimmune encephalomyelitis. J Clin Invest 116:447-455.

Dirnagl U, Klehmet J, Braun JS, Harms H, Meisel C, Ziemssen T, Prass K, Meisel A (2007) Stroke-induced immunodepression: experimental evidence and clinical relevance. Stroke 38:770-773.

Dziedzic T, Slowik A, Szczudlik A (2004) Nosocomial infections and immunity: lesson from brain-injured patients. Crit Care 8:266-270.

Emilsson V, Liu YL, Cawthorne MA, Morton NM, Davenport M (1997) Expression of the functional leptin receptor mRNA in pancreatic islets and direct inhibitory action of leptin on insulin secretion. Diabetes 46:313-316.

Faggioni R, Fantuzzi G, Gabay C, Moser A, Dinarello CA, Feingold KR, Grunfeld C (1999) Leptin deficiency enhances sensitivity to endotoxin-induced lethality. Am J Physiol 276:R136-R142.

Fantuzzi G, Faggioni R (2000) Leptin in the regulation of immunity, inflammation, and hematopoiesis. J Leukoc Biol 68:437-446.

Farooqi IS, Matarese G, Lord GM, Keogh JM, Lawrence E, Agwu C, Sanna V, Jebb SA, Perna F, Fontana S, Lechler RI, DePaoli AM, O’Rahilly S (2002) Beneficial effects of leptin on obesity, $\mathrm{T}$ cell hyporesponsiveness, and neuroendocrine/metabolic dysfunction of human congenital leptin deficiency. J Clin Invest 110:1093-1103.

Flier JS (1998) Lowered leptin slims immune response. Nat Med 4:1124-1125.

Friedman JM (2002) The function of leptin in nutrition, weight, and physiology. Nutr Rev 60:S1-S14; discussion S68-S84:85-87.

Gainsford T, Willson TA, Metcalf D, Handman E, McFarlane C, Ng A, Nicola NA, Alexander WS, Hilton DJ (1996) Leptin can induce proliferation, differentiation, and functional activation of hemopoietic cells. Proc Natl Acad Sci U S A 93:14564-14568.

Halaas JL, Gajiwala KS, Maffei M, Cohen SL, Chait BT, Rabinowitz D, Lallone RL, Burley SK, Friedman JM (1995) Weight-reducing effects of the plasma protein encoded by the obese gene. Science 269:543-546.

Hed J (1986) Methods for distinguishing ingested from adhering particles. Methods Enzymol 132:198-204.

Henry BA, Goding JW, Alexander WS, Tilbrook AJ, Canny BJ, Dunshea F, Rao A, Mansell A, Clarke IJ (1999) Central administration of leptin to ovariectomized ewes inhibits food intake without affecting the secretion of hormones from the pituitary gland: evidence for a dissociation of effects on appetite and neuroendocrine function. Endocrinology 140:1175-1182. 
Hotchkiss RS, Karl IE (2003) The pathophysiology and treatment of sepsis. N Engl J Med 348:138-150.

Hsu A, Aronoff DM, Phipps J, Goel D, Mancuso P (2007) Leptin improves pulmonary bacterial clearance and survival in ob/ob mice during pneumococcal pneumonia. Clin Exp Immunol 150:332-339.

Huston JM, Gallowitsch-Puerta M, Ochani M, Ochani K, Yuan R, RosasBallina M, Ashok M, Goldstein RS, Chavan S, Pavlov VA, Metz CN, Yang H, Czura CJ, Wang H, Tracey KJ (2007) Transcutaneous vagus nerve stimulation reduces serum high mobility group box 1 levels and improves survival in murine sepsis. Crit Care Med 35:2762-2768.

Ikejima S, Sasaki S, Sashinami H, Mori F, Ogawa Y, Nakamura T, Abe Y, Wakabayashi K, Suda T, Nakane A (2005) Impairment of host resistance to Listeria monocytogenes infection in liver of $\mathrm{db} / \mathrm{db}$ and $\mathrm{ob} / \mathrm{ob}$ mice. Diabetes 54:182-189.

Kamezaki K, Shimoda K, Numata A, Haro T, Kakumitsu H, Yoshie M, Yamamoto M, Takeda K, Matsuda T, Akira S, Ogawa K, Harada M (2005) Roles of Stat3 and ERK in G-CSF signaling. Stem Cells 23:252-263.

Kowalski TJ, Liu SM, Leibel RL, Chua SC Jr (2001) Transgenic complementation of leptin-receptor deficiency. I. Rescue of the obesity/diabetes phenotype of LEPR-null mice expressing a LEPR-B transgene. Diabetes 50:425-435.

Kurihara T, Warr G, Loy J, Bravo R (1997) Defects in macrophage recruitment and host defense in mice lacking the CCR2 chemokine receptor. J Exp Med 186:1757-1762.

Lago R, Gómez R, Lago F, Gómez-Reino J, Gualillo O (2008) Leptin beyond body weight regulation: current concepts concerning its role in immune function and inflammation. Cell Immunol 252:139-145.

Lam QL, Lu L (2007) Role of leptin in immunity. Cell Mol Immunol 4:1-13.

Lee WL, Harrison RE, Grinstein S (2003) Phagocytosis by neutrophils. Microbes Infect 5:1299-1306.

López M, Lelliott CJ, Tovar S, Kimber W, Gallego R, Virtue S, Blount M, Vázquez MJ, Finer N, Powles TJ, O’Rahilly S, Saha AK, Diéguez C, VidalPuig AJ (2006) Tamoxifen-induced anorexia is associated with fatty acid synthase inhibition in the ventromedial nucleus of the hypothalamus and accumulation of malonyl-CoA. Diabetes 55:1327-1336.

Lord GM, Matarese G, Howard JK, Baker RJ, Bloom SR, Lechler RI (1998) Leptin modulates the T-cell immune response and reverses starvationinduced immunosuppression. Nature 394:897-901.

Lu B, Rutledge BJ, Gu L, Fiorillo J, Lukacs NW, Kunkel SL, North R, Gerard C, Rollins BJ (1998) Abnormalities in monocyte recruitment and cytokine expression in monocyte chemoattractant protein 1-deficient mice. J Exp Med 187:601-608.

Mancuso P, Gottschalk A, Phare SM, Peters-Golden M, Lukacs NW, Huffnagle GB (2002) Leptin-deficient mice exhibit impaired host defense in Gram-negative pneumonia. J Immunol 168:4018-4024.

Mancuso P, Huffnagle GB, Olszewski MA, Phipps J, Peters-Golden M (2006) Leptin corrects host defense defects after acute starvation in murine pneumococcal pneumonia. Am J Respir Crit Care Med 173:212-218.

Mandel MA, Mahmoud AA (1978) Impairment of cell-mediated immunity in mutation diabetic mice (db/db). J Immunol 120:1375-1377.

Meisel C, Schwab JM, Prass K, Meisel A, Dirnagl U (2005) Central nervous system injury-induced immune deficiency syndrome. Nat Rev Neurosci 6:775-786.

Mocellin S, Panelli MC, Wang E, Nagorsen D, Marincola FM (2003) The dual role of IL-10. Trends Immunol 24:36-43.

Montecucco F, Bianchi G, Gnerre P, Bertolotto M, Dallegri F, Ottonello L (2006) Induction of neutrophil chemotaxis by leptin: crucial role for $\mathrm{p} 38$ and Src kinases. Ann N Y Acad Sci 1069:463-471.

Moore KW, de Waal Malefyt R, Coffman RL, O'Garra A (2001) Interleukin-10 and the interleukin-10 receptor. Annu Rev Immunol 19:683-765.

Murphey ED, Lin CY, McGuire RW, Toliver-Kinsky T, Herndon DN, Sherwood ER (2004) Diminished bacterial clearance is associated with decreased IL-12 and interferon-gamma production but a sustained proinflammatory response in a murine model of postseptic immunosuppression. Shock 21:415-425.

Nagashima K, Nakai S, Tanaka M, Kanosue K (2000) Neuronal circuitries involved in thermoregulation. Auton Neurosci 85:18-25.

Nagata S, Tsuchiya M, Asano S, Kaziro Y, Yamazaki T, Yamamoto O, Hirata Y, Kubota N, Oheda M, Nomura H (1986) Molecular cloning and ex- pression of cDNA for human granulocyte colony-stimulating factor. Nature 319:415-418.

Nogueiras R, Wiedmer P, Perez-Tilve D, Veyrat-Durebex C, Keogh JM, Sutton GM, Pfluger PT, Castaneda TR, Neschen S, Hofmann SM, Howles PN, Morgan DA, Benoit SC, Szanto I, Schrott B, Schürmann A, Joost HG, Hammond C, Hui DY, Woods SC, Rahmouni K, Butler AA, Farooqi IS, O’Rahilly S, Rohner-Jeanrenaud F, Tschöp MH (2007) The central melanocortin system directly controls peripheral lipid metabolism. J Clin Invest 117:3475-3488.

Ozata M, Ozdemir IC, Licinio J (1999) Human leptin deficiency caused by a missense mutation: multiple endocrine defects, decreased sympathetic tone, and immune system dysfunction indicate new targets for leptin action, greater central than peripheral resistance to the effects of leptin, and spontaneous correction of leptin-mediated defects. J Clin Endocrinol Metab 84:3686-3695.

Ozer J, Ratner M, Shaw M, Bailey W, Schomaker S (2008) The current state of serum biomarkers of hepatotoxicity. Toxicology 245:194-205.

Pavlov VA, Tracey KJ (2006) Controlling inflammation: the cholinergic anti-inflammatory pathway. Biochem Soc Trans 34:1037-1040.

Pavlov VA, Ochani M, Gallowitsch-Puerta M, Ochani K, Huston JM, Czura CJ, Al-Abed Y, Tracey KJ (2006) Central muscarinic cholinergic regulation of the systemic inflammatory response during endotoxemia. Proc Natl Acad Sci U S A 103:5219-5223.

Pelleymounter MA, Cullen MJ, Baker MB, Hecht R, Winters D, Boone T, Collins F (1995) Effects of the obese gene product on body weight regulation in ob/ob mice. Science 269:540-543.

Peters JH, Simasko SM, Ritter RC (2006a) Modulation of vagal afferent excitation and reduction of food intake by leptin and cholecystokinin. Physiol Behav 89:477-485.

Peters JH, Ritter RC, Simasko SM (2006b) Leptin and CCK selectively activate vagal afferent neurons innervating the stomach and duodenum. Am J Physiol Regul Integr Comp Physiol 290:R1544-R1549.

Pittet D, Thiévent B, Wenzel RP, Li N, Auckenthaler R, Suter PM (1996) Bedside prediction of mortality from bacteremic sepsis. A dynamic analysis of ICU patients. Am J Respir Crit Care Med 153:684-693.

Prass K, Meisel C, Höflich C, Braun J, Halle E, Wolf T, Ruscher K, Victorov IV, Priller J, Dirnagl U, Volk HD, Meisel A (2003) Stroke-induced immunodeficiency promotes spontaneous bacterial infections and is mediated by sympathetic activation reversal by poststroke $\mathrm{T}$ helper cell type 1-like immunostimulation. J Exp Med 198:725-736.

Rajala MW, Qi Y, Patel HR, Takahashi N, Banerjee R, Pajvani UB, Sinha MK, Gingerich RL, Scherer PE, Ahima RS (2004) Regulation of resistin expression and circulating levels in obesity, diabetes, and fasting. Diabetes 53:1671-1679.

Remick DG, Bolgos GR, Siddiqui J, Shin J, Nemzek JA (2002) Six at six: interleukin-6 measured $6 \mathrm{~h}$ after the initiation of sepsis predicts mortality over 3 days. Shock 17:463-467.

Santos-Alvarez J, Goberna R, Sánchez-Margalet V (1999) Human leptin stimulates proliferation and activation of human circulating monocytes. Cell Immunol 194:6-11.

Schlag G, Redl H, Hallström S (1991) The cell in shock: the origin of multiple organ failure. Resuscitation 21:137-180.

Siegmund B, Sennello JA, Jones-Carson J, Gamboni-Robertson F, Lehr HA, Batra A, Fedke I, Zeitz M, Fantuzzi G (2004) Leptin receptor expression on $\mathrm{T}$ lymphocytes modulates chronic intestinal inflammation in mice. Gut 53:965-972.

Szöllösi J, Trón L, Damjanovich S, Helliwell SH, Arndt-Jovin D, Jovin TM (1984) Fluorescence energy transfer measurements on cell surfaces: a critical comparison of steady-state fluorimetric and flow cytometric methods. Cytometry 5:210-216.

Takahashi H, Tsuda Y, Takeuchi D, Kobayashi M, Herndon DN, Suzuki F (2004) Influence of systemic inflammatory response syndrome on host resistance against bacterial infections. Crit Care Med 32:1879-1885.

Tilg H, Moschen AR (2006) Adipocytokines: mediators linking adipose tissue, inflammation and immunity. Nat Rev Immunol 6:772-783.

Tracey KJ (2007) Physiology and immunology of the cholinergic antiinflammatory pathway. J Clin Invest 117:289-296.

Tschöp J, Martignoni A, Goetzman HS, Choi LG, Wang Q, Noel JG, Ogle CK, Pritts TA, Johannigman JA, Lentsch AB, Caldwell CC (2008) Gammadelta T cells mitigate the organ injury and mortality of sepsis. J Leukoc Biol 83:581-588.

van den Blink B, Branger J, Weijer S, Gupta A, van Deventer SJ, Peppelenbosch 
MP, van der Poll T (2004) P38 mitogen activated protein kinase is involved in the downregulation of granulocyte CXC chemokine receptors 1 and 2 during human endotoxemia. J Clin Immunol 24:37-41.

Wang H, Yu M, Ochani M, Amella CA, Tanovic M, Susarla S, Li JH, Wang H, Yang H, Ulloa L, Al-Abed Y, Czura CJ, Tracey KJ (2003) Nicotinic acetylcholine receptor alpha7 subunit is an essential regulator of inflammation. Nature 421:384-388.

Wichterman KA, Baue AE, Chaudry IH (1980) Sepsis and septic shock-a review of laboratory models and a proposal. J Surg Res 29:189-201.

Wieland CW, Florquin S, Chan ED, Leemans JC, Weijer S, Verbon A, Fantuzzi G, van der Poll T (2005) Pulmonary Mycobacterium tuberculosis infection in leptin-deficient ob/ob mice. Int Immunol 17:1399-1408.
Williams KW, Zsombok A, Smith BN (2007) Rapid inhibition of neurons in the dorsal motor nucleus of the vagus by leptin. Endocrinology 148: $1868-1881$.

Zanotti S, Kumar A, Kumar A (2002) Cytokine modulation in sepsis and septic shock. Expert Opin Investig Drugs 11:1061-1075.

Zhang Y, Proenca R, Maffei M, Barone M, Leopold L, Friedman JM (1994) Positional cloning of the mouse obese gene and its human homologue. Nature 372:425-432.

Zu YL, Qi J, Gilchrist A, Fernandez GA, Vazquez-Abad D, Kreutzer DL, Huang CK, Sha'afi RI (1998) p38 mitogen-activated protein kinase activation is required for human neutrophil function triggered by TNFalpha or FMLP stimulation. J Immunol 160:1982-1989. 